\title{
DEVELOPING A MODEL OF PROFESSIONAL IDENTITY IN MEDICAL STUDENTS: THE ROLE OF MOTIVATION AND PARTICIPATION
}

\author{
Yoga Pamungkas Susani*, Gandes Retno Rahayu**, Rossi Sanusi**, Yayi Suryo Prabandari***, \\ Harsono Mardiwiyoto** \\ * Medical Education Unit, Faculty of Medicine, Universitas Mataram, Mataram - INDONESIA \\ ** Department of Medical Education and Bioethics, Faculty of Medicine, Publich Health and Nursing \\ Universitas Gadjah Mada, Yogyakarta - INDONESIA \\ *** Department of Public Health, Faculty of Medicine, Publich Health and Nursing Universitas Gadjah \\ Mada, Yogyakarta - INDONESIA
}

\begin{abstract}
Background: It is very important to develop professional identity among medical students, as it will affect how they work in the future. Factors affecting professional identity in medical education context need to be explored. This study aimed to develop a model of professional identity in medical students which examine the role of motivation, self-efficacy, personal reflection, social interaction, curriculum in action perceived by students and participation in determining professional identity.

Methods: A cross-sectional survey was conducted among medical students in Mataram University. A total of 303 pre-clinical (year 1 to 4) and clinical students (year 5 to 6) filled out the questionnaires. Partial least square - structural equation model analysis was performed.

Results: The modification model had a good model fit (GoF 0.404). The average path coefficient was 0.303 ( $p<0.001)$ and the adjusted average $R$ square was $0.321(p<0.001)$. Forty percent of variance in professional identity could be explained by motivation $(\beta=0.51, p<0.001, f 2=0.281)$ and participation $(\beta=0.32, p<0.001, f 2=0.118)$.

Conclusions: Motivation and participation of medical students may influence the professional identity. Based on the model, within the medical education processes, academic motivation of students should be maintained and fostered and participation should be supported.
\end{abstract}

Keywords: professional identity, participation, self-efficacy, motivation, social interaction, curriculum in action, personal reflection

\section{ABSTRAK}

Latar belakang: Proses pengembangan identitas profesional pada mahasiswa kedokteran sangat penting karena akan berpengaruh pada praktik klinik. Variabel-variabel yang berpengaruh terhadap identitas profesional dalam pendidikan kedokteran perlu digali lebih lanjut. Penelitian ini bertujuan untuk mengembangkan model identitas profesional mahasiswa kedokteran dengan menilai peran variabel motivasi, efikasi diri, refleksi personal, interaksi sosial, persepsi mahasiswa terhadap kurikulum aksi dan partisipasi terhadap identitas profesional.

Metode: survei potong lintang dilakukan kepada mahasiswa kedokteran Universitas Mataram. Sebanyak 303 mahasiswa pra-klinik dan klinik mengisi kuesioner. Analisis model dilakukan dengan partial least square-structural equation model. Hasil: Model modifikasi memiliki kecocokan model GoF 0,404. Rerata koefisien jalur (APC) sebesar 0,303 ( $p<0,001)$ dan rerata koefisien determinasi (adjusted average $R$ square) adalah 0,321 ( $p<0,001$ ). Sebesar $40 \%$ variansi identitas profesional dapat dijelaskan oleh variabel motivasi $(\beta=0,51 ; p<0,001 ; f 2=0,281)$ dan partisipasi $(\beta 0,32 ; p<0,001$; $f 2=0,118)$.

contact: yoga_pamungkas_s@yahoo.com 
Kesimpulan: Motivasi dan partisipasi mahasiswa kedokteran dapat berpengaruh terhadap identitas profesional. Berdasarkan model, dalam proses pendidikan dokter, motivasi akademik mahasiswa harus dijaga dan ditingkatkan sedangkan partisipasi harus didukung.

Kata kunci: identitas profesional, partisipasi, efikasi diri, motivasi, interaksi sosial, kurikulum aksi, refleksi personal

\section{INTRODUCTION}

Professional identity plays an important role for doctors in practice., ${ }^{1,2}$ For medical students, professional identity is an internal condition and characters that is developed during the process of medical education. ${ }^{3}$ Professional identity is a dynamic relation during the lifespan. An individual defines him/herself by exploring life experience through participation in group or community. The development of professional identity is shifted from an individual-focused to a more relational and integrated one when someone perform a profession. ${ }^{4}$

In the theory of communities of practice $(\mathrm{CoP})$, participation is the source of identity. ${ }^{1}$ Participation is activities that develop the sense of belonging and become the means for identification. Participation is a learning process that can be performed in three forms of modes of identification, for instance engagement, imagination, and alignment. ${ }^{5}$ Engagement is a direct experience including all activities done alone or together associated with the community, e.g. engaging in discussions, using or producing an artifact. ${ }^{5}$ Imagination is constructing an image about self, the community and outside world. Imagination is essential to reflect the situation and to explore the self and the community. It can create the relation of identification process derived from engagement. Alignment is a process to select and to form the commitment. One ensures that participation performed is in accordance with the concept or the principle embedded in the community and convinces that the local activity is also in accordance with the other processes that can be accepted globally. ${ }^{5}$

Considering the importance of the participation in the professional identity, variables which might affect the student's participation need to be investigated. There are several variables which could influence student's participation in workplace, i.e: human interactions; curriculum factors; a positive state of mind including motivation, sense of identity, confidence and sense of reward; and practical competence. ${ }^{6}$ In the present study, we took social interaction, curriculum in action, motivation, selfefficacy, and personal reflection as predictor variable of participation.

Several studies have tried to link motivation with participation in the CoP. ${ }^{7,8}$ Motivation influences engagement and participation. ${ }^{7,9}$ Participation may be sustained when there is an internal or awareness feeling in performing the process and controlling a certain action. The theory of self-determination explains the role of motivation to make one choice to start and regulate an action. ${ }^{10}$ In addition to selfdetermination, self-efficacy is an important factor that convinces and encourages oneself to perform an action. Self-efficacy is a confidence to self ability in arranging and completing an action that is needed to produce an achievement. ${ }^{11}$ Self-efficacy and motivation are two important constructs that determine achievement and performance. ${ }^{12}$

This study also investigated the construct of personal reflection that assesses the ability of a person's reflection of the experiences themselves. Reflection can be a mediator between experience and identity. ${ }^{13}$ This study measure the student's ability to do reflection instead of the intensity of reflection which done by the students. Thus, the construct of personal reflection is placed as a predictor of participation.

Besides the 3 constructs of internal factor of self above, we also examined the social interaction and curriculum in action perceived by students which represent external factor. The medical education environment should provide support and facilitate the three forms of participation. Support can be 
obtained from the formal curriculum and hidden curriculum. The role of informal and hidden curriculum might even be more important in forming professional identity. ${ }^{14}$

From the description above, the hypothesis in this study are: 1) Motivation, self-efficacy and personal reflection, each construct, has positive association with participation; 2) Social interaction and curriculum in action perceived by students, each construct, has positive association with participation; 3) The participation as the mediator variables has positive association with professional identity.

The study also examines the differences between preclinical and clinical context. This was conducted due to the educational environment which is different between these two stages. ${ }^{15}$

\section{METHODS}

This study was part of a research project involving two research location, for instance UNRAM and UGM.16 This research has received permission from Faculty of Medicine, University of Gadjah Mada (UGM) and Faculty of Medicine, University of Mataram (UNRAM). Ethical approval for the present study was obtained from the Ethical Committee, Faculty of Medicine, UGM. This project begins with the development of four instruments that will be used to test the model. The development process of those instruments includes determining the aims, developing blue print, conducting qualitative research to explore the phenomena in medical students, developing items from the results of qualitative research, experts review and readability test to medical student with continuous improvement, conducting survey and factor analysis. This study used a cross sectional survey which was conducted to all medical students of Faculty of Medicine, Mataram University.

The validity and reliability of all instruments had been evaluated in this study. Confirmatory factor analysis with partial least square structural equation model (PLS-SEM) was conducted. Convergent validity was evaluated by the AVE value $(>0.5)$. Good discriminant validity among factors in instrument was indicated by the root square AVE which is greater than the correlations among factors. Good reliability was indicated by the composite reliability coefficient which was > 0.7. All instruments had items with loading factor $>0.7$. Indicator weights were all significant $(<0.01)$. There was no multicollinearity problem between instruments (VIF<3.3). These selfdeveloped instrument are as follows:

1. Professional identity, which consists of 17 items, measuring the perception of students towards their identity as a member of medical profession community, with the scale of $1-7$ $(1=$ very unsuitable, $7=$ very suitable $)$. The instrument evaluates perceived comfort to be in the community of medical profession, enthusiasm to engage and effectiveness to play a role in medical profession. The instrument showed a good composite reliability (0.797) and good convergent validity (AVE 0.572, comfort 0.530; enthusiasm to engage 0.601 ; effectiveness 0.647).

2. Participation, which consist of 35 items, evaluating the intensity of activities performed both individually and in groups associated with the membership in the community of medical profession, inside or outside the medical school during the past year. The instrument assesses student's activities in learning about the profession, clinical activities, medical activities in the society, discussions, interactions with peer and other profession, reflection and evaluation activities. The scale used was 1-7 $(1=$ almost never, 7 = almost always). Instrument showed a good composite reliability (0.870) and good convergent validity (AVE 0.770).

3. Perceived curriculum in action, which consist of 20 items, measures whether the curriculum provides support for engagement and imagination, curriculum convergence and availability of feedback for students. The engagement support in curriculum is indicated by providing of activities that support interactions among students or with teachers (mutuality), providing opportunities for students to show their competence and providing chance to clinical contact with patients. The imagination support measures the curriculum 
ability to orient students to the real context of medical profession and to facilitate students to reflect their experience. The Likert scale 1-5 $(1=$ totally disagree until $5=$ totally agree $)$ was used. The instrument showed a good composite reliability (0.815) and good convergent validity (AVE 0.526).

4. Social interaction was measured using a selfdeveloped instrument which consists of 13 items and measures student' interaction with peers, doctors and other health profession. The Likert scale 1-5 $(1=$ totally disagree until $5=$ totally agree) was used. The instrument had a good composite reliability (0.772) and good convergent validity (AVE 0.628).

Three variables were assessed using instruments adapted from existing instruments. The adaptation processes included a back-to-back translation from Indonesian to into English to ensure similar meaning. These variables were:

1. Motivation, which was measured using an instrument adapted from the Academic Motivation Scale (AMS). ${ }^{17}$ AMS measures motivation based on self-determination theory. There are 7 subscales in AMS, i.e. intrinsic motivation to know, to accomplish and to experience stimulation; external, introjected and identified regulation which included in external motivation; and amotivation. The instrument showed a good composite reliability $(0.900)$ with good convergent validity (AVE 0.692). Only 24 items showed loading factor of $>0.7$ and were included in the model test.

2. Self-efficacy, which was assessed using an instrument adapted from the College SelfEfficacy Inventory (CSEI ). ${ }^{18}$ CSEI measures selfefficacy of students in their ability to perform the course-related tasks. This scale contains of 4 factors (course, roommate, social and social integration). Items with loading factor of $<0.7$ were not included in the analysis. The instrument had a good composite reliability (0.836) with good convergent validity (AVE 0.562).

3. Personal reflection was measured using adapted Groningen Reflection Ability scale (GRAS). ${ }^{19}$ Only 6 items in 3 factors (self reflection, emphatetic reflection, and reflective communication) which had loading factor of $>$ 0.7 were included in the model analysis to have good composite reliability (0.799) and good convergent validity (AVE 0.570).

The data was collected at the end of academic year. The questionnaires are self-report type, equipped with clear instructions, including explanations about what is the aim of the instrument, what is to be assessed, how to assess, statement that the participation in this research is voluntary and the guarantee of the data confidentiality. This is not an anonymous survey. For pre-clinical students, the data was collected in class for each year. This may improve the reliability of data collection. For clinical students, the data can not be collected in class due to differences in the schedule at each clinical placement. Data was collected by the personal administration. The clear instructions in each questionnaire may improve the reliability of data collection.

For testing the model, data was analyzed using PLS-SEM. This analysis method allows estimating complex cause-effect relationship model. PLS-SEM could be applied in research project with limited participants and skewed distribution data. ${ }^{20}$

There are 2 kinds of model tested by PLS-SEM: measurement (outer) model and structural (inner) model. Measurement model represent the relationship of observed variables to latent variables. It give information about the validity and reliability of measured variables. Structural model represent the relationship between latent variables. Software WarpPLS was used. Algorithm analysis methods used for evaluating outer model was PLS mode-A, while for evaluating inner model was Warp3. Bootstrapping was used as resampling method with number of 500 .

\section{RESULTS AND DISCUSSION}

From the total of 347 total pre-clinical and clinical students, 303 completed the questionnaires (87.3\%). There are 65 from 96 total clinical students completed the questionnaires. The GPA between clinical students who completed the questionnaires did not differ significantly from those who did not complete 
questionnaires. Among pre-clinical students, 5.2\% did not complete the questionnaire. Their GPAs were significantly lower from those who completed the questionnaire. Characteristics of subjects were described in Table 1.

Table 1. Characteristics and descriptive analysis of subjects

\begin{tabular}{|c|c|c|c|c|c|c|c|}
\hline \multirow{2}{*}{ Characteristics } & \multicolumn{6}{|c|}{ Year } & \multirow{2}{*}{ Total } \\
\hline & I & II & III & IV & V & VI & \\
\hline $\mathrm{N}$ participant & 62 & 61 & 64 & 51 & 32 & 33 & 303 \\
\hline$\%$ participant from total & 98.4 & 93.8 & 97 & 89.5 & 68.1 & 67.3 & 87.32 \\
\hline \multicolumn{8}{|l|}{ Sex } \\
\hline Male & 17 & 18 & 19 & 23 & 14 & 6 & 97 \\
\hline Female & 45 & 43 & 45 & 28 & 18 & 27 & 206 \\
\hline \multicolumn{8}{|l|}{ Mean of GPA } \\
\hline Participants & 3.05 & 3.08 & 3.11 & 3.09 & 2.75 & 3.01 & 3.04 \\
\hline Non & 0.88 & 1.31 & 1.84 & 2.81 & 2.87 & 2.98 & 2.67 \\
\hline \multicolumn{8}{|l|}{ Mean of variables } \\
\hline Social Interaction & 3.72 & 3.55 & 3.63 & 3.56 & 3.43 & 3.43 & 3.58 \\
\hline Curriculum in action & 3.79 & 3.62 & 3.63 & 3.69 & 3.64 & 3.58 & 3.67 \\
\hline Personal Reflection & 3.71 & 3.72 & 3.76 & 3.73 & 3.58 & 3.61 & 3.70 \\
\hline Motivation & 5.76 & 5.70 & 5.72 & 5.32 & 5.37 & 5.06 & 5.55 \\
\hline Self-efficacy & 6.38 & 5.95 & 6.35 & 4.71 & 6.50 & 6.15 & 5.99 \\
\hline Participation & 3.39 & 3.53 & 3.72 & 3.90 & 4.71 & 4.92 & 3.88 \\
\hline Professional Identity & 4.44 & 4.76 & 4.77 & 4.67 & 5.15 & 5.19 & 4.77 \\
\hline
\end{tabular}

Professional identity was higher in students with higher education year. The highest mean was found in year 6 students $(5.19 \pm 0.82)$ and the lowest mean was found in the year 1 students $(4.44 \pm 0.89)$. Participation was also higher in students with higher education year. The highest mean of participation was found in year 6 students $(4.92 \pm 0.59)$ and the lowest mean was found in year 1 students $(3.39 \pm$ 0.89).

1. Analysis of proposed model

Model 1 (proposed model) analyzed the role of motivation, self-efficacy, personal reflection, perception of the curriculum in action, and social interaction as predictors of participation (Figure 1). Participation positioned as the mediator toward professional identity. The results found that self-efficacy, social interaction and perceived curriculum in action significantly influenced participation, whereas personal reflection and motivation was not significantly correlated to participation $(r=0.065, p=0.335 ; 0.111, p=0.111$ respectively). Motivation significantly associated with professional identity. 


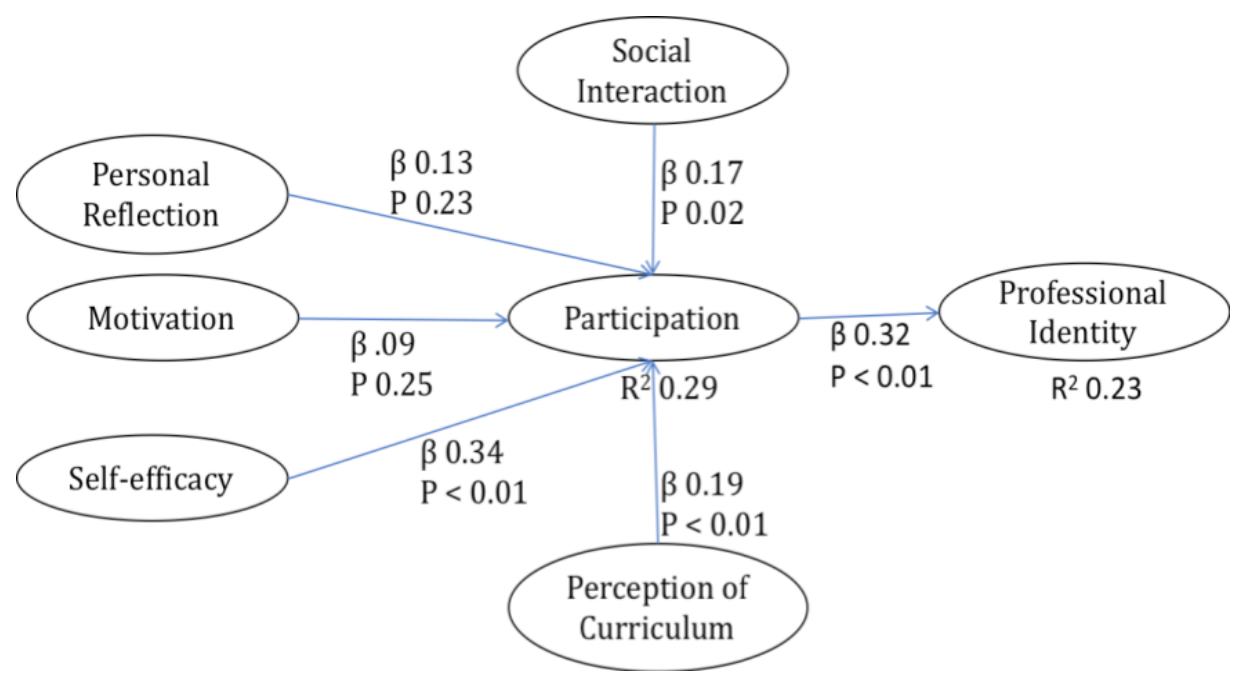

Figure 1.The proposed model of professional identity

2. Modification model

The non significant associations were deleted in model 2 (modification model). Model 2 showed that motivation was significantly associated with professional identity. Model 2 had a good model fit (Table 2), with average R2 in moderate criteria and a significant path coefficient (Table 2, Figure 2). The SE for the whole path coefficients was $\leq$ 0.074 . Model 2 was referred to as professional identity model (Figure 2).

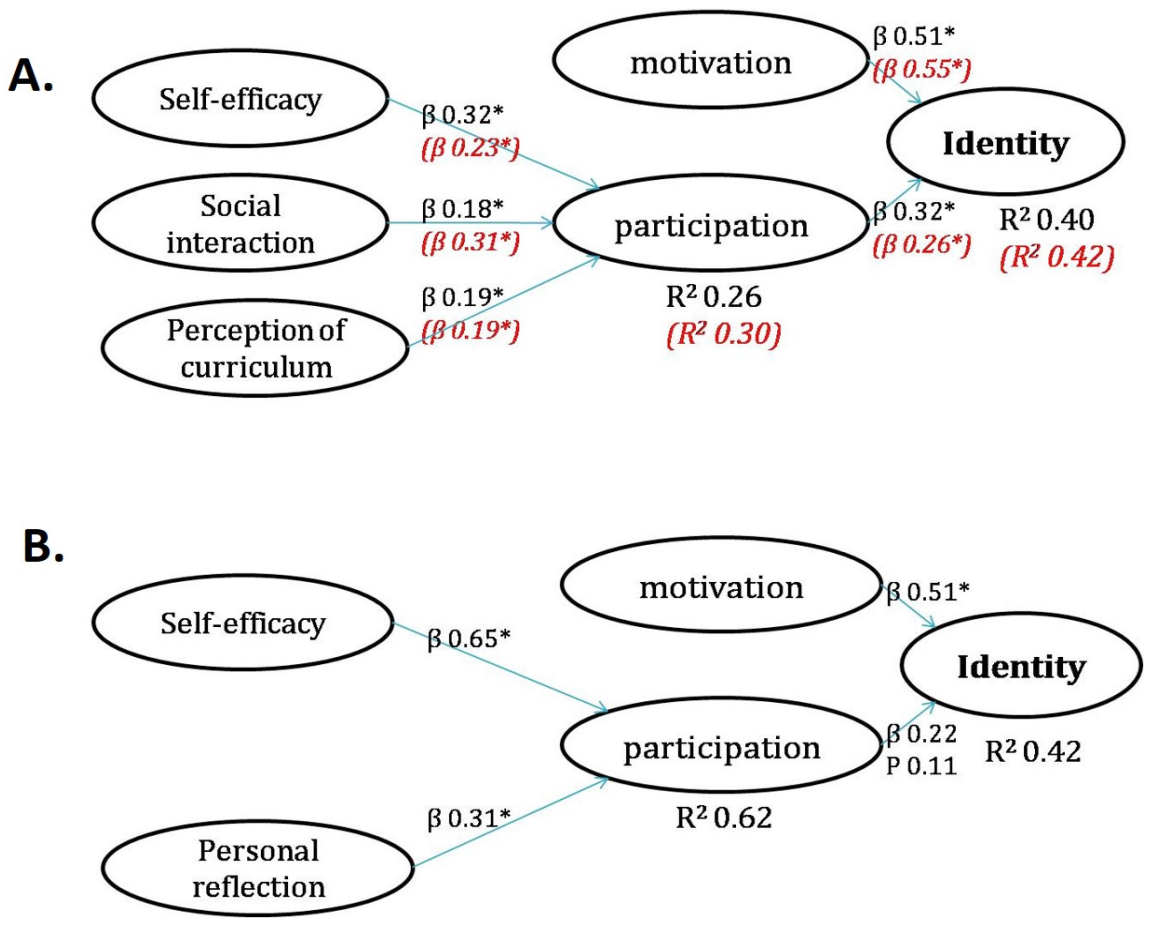

Figure 2. The difference between the model of professional identity in pre-clinical (A) and in clinical medical students (B). Figure 2A shows the modification model of professional identity in medical students. The red italic characters indicate the results in pre-clinical only medical students. Note that the greatest effect to participation in the pre-clinical model was the social interaction, whereas in the clinical model was self-efficacy. ${ }^{*} \mathrm{p}<0,01$ 
From the outer model evaluation or measurement model analysis (Table 3), the composite reliability coefficients for the constructs were all above the accepted level of 0.70 . The measurement analysis revealed that all measures were significant and above the 0.60 loading level. The construct validity was assessed for convergent and discriminant validity.
All constructs showed good convergent validity, as indicated by the average variance extracted (AVE) of > 0.5. The discriminant validity was good, as indicated by comparison of the square roots of AVEs to the correlation between variables (AVE should greater than correlation between constructs).

Table 2. Comparison of the structural model of professional identity

\begin{tabular}{lcccc} 
& Model 1 & Model 2 & Pre-clinic & Clinic \\
APC & $0.234^{*}$ & $0.303^{*}$ & $0.306^{*}$ & $0.423^{*}$ \\
ARS & $0.260^{*}$ & $0.329^{*}$ & $0.361^{*}$ & $0.524^{*}$ \\
AARS & $0.250^{*}$ & $0.321^{*}$ & $0.352^{*}$ & $0.501^{*}$ \\
AVIF & 1.285 & 1.212 & 1.256 & 1.188 \\
AFVIF & 1.454 & 1.515 & 1.621 & 1.884 \\
GoF & 0.371 & 0.404 & 0.445 & 0.553 \\
SPR & 1.000 & 1.000 & 1.000 & 1.000 \\
RSCR & 1.000 & 1.000 & 1.000 & 1.000 \\
SSR & 1.000 & 1.000 & 1.000 & 1.000 \\
NLBCDR & 0.917 & 1.000 & 1.000 & 1.000 \\
\hline
\end{tabular}

${ }^{*} \mathrm{P}<0.001$; APC (average path coefficients), ARS (average R square), AARS (adjusted average R square) $0.25 \leq$ AARS $\leq 0.45$ means moderate; $\leq$, AVIF and AFVIF $<3.3$ indicate no multicollinearity problem; GoF $\geq 0.36$ great model fit; SPR, RSCR, SSR and NLBCDR were adequate

The effect size of self-efficacy, social interaction and curriculum in action perceived by students was 0.130 , 0.062, and 0.066 , respectively. Self-efficacy, social interaction and curriculum in action had an indirect effect to professional identity $[0.102(\mathrm{p}=0.002) ; 0.056$ $(\mathrm{p}=0.017)$ and $0.058(\mathrm{p}=0.009)$, respectively]. This implies that participation mediated the association between self-efficacy, social interaction, perception of curriculum in action and professional identity.

Table 3. Outer model evaluation of professional identity model

\begin{tabular}{lcccccc} 
& Motivation & Self-efficacy & $\begin{array}{c}\text { Social } \\
\text { interaction }\end{array}$ & Curriculum & Participation & Identity \\
$\mathrm{R}^{2}$ & & & & & 0.257 & 0.400 \\
Adjusted R & & & & 0.247 & 0.394 \\
Composite reliability & 0.889 & 0.840 & 0.773 & 0.804 & 0.889 & 0.809 \\
AVE & 0.549 & 0.569 & 0.632 & 0.514 & 0.502 & 0.600 \\
Full collin. VIF & 1.617 & 1.272 & 1.620 & 1.683 & 1.483 & 1.672 \\
$\mathrm{Q}^{2}$ coefficients & & & & & 0.269 & 0.404 \\
\hline
\end{tabular}


3. Model of pre-clinical and clinical

Stratified analysis by pre-clinical and clinical education showed that in the pre-clinical model, the path coefficient of social interaction towards participation was dominant (Figure 2). Self-efficacy, social interaction and curriculum in action perceived by students had a small effect size towards participation $(0.077,0.150$, and 0.074 , respectively). The indirect effect of the 3 constructs towards professional identity was $0.059(\mathrm{p}=0.018), 0.082 \quad(\mathrm{p}=0.002)$, and $0.049 \quad(\mathrm{p}=0.015)$. These significant indirect effects indicated that participation mediated the association between the 3 constructs and professional identity.

Figure 2B shows the association between constructs in the clinical professional identity model. In this model, social interaction and curriculum in action perceived by students were excluded, because the path coefficients were not significant $(-0.028, \mathrm{p}=0.425$ and $0.133, \mathrm{p}=0.159$, respectively). The $\mathrm{R} 2$ of participation in this model was 0.62 (large). Personal reflection and self-efficacy had moderate and large effect sizes towards participation $(0.15$ and 0.48 , respectively). Participation did not have a significant direct effect towards professional identity $(\mathrm{p}=0.11)$. However, if participation is directed towards motivation, participation showed a significant effect to motivation ( $\square=0.46, p=0.002$, with effect size of 0.215 ), and an indirect effect towards professional identity (0.229, $\mathrm{p}=0.015)$. It indicated that motivation could be a mediator between participation and professional identity.

Our results showed that clinical students had higher participation than pre-clinical students. This might be due to more opportunities for clinical practice in clinical education. With ethical considerations and mastery of competencies, pre-clinical students are still limited to play a role in clinical practice and patient contact. However, in medical education, participation should not be seen as limited to clinical practice. ${ }^{21}$ Faculty could encourage pre-clinical students to engage in social activity, education or training programmes for lay social communities and fostering reflection. Some programs for pre-clinical students, in other studies, indicated could develop a professional identity, for instance conducting clinical audit, ${ }^{22}$ collaborative drawing, ${ }^{23}$ or producing medical comic which shows professional characters or conflicts in medical. ${ }^{24}$

This study aimed to investigate the role of variables to professional identity. The results of the analysis failed to support two hypotheses. Motivation and personal reflection did not have significant association with participation. Motivation can not explain the variance of participation. The first year students have the highest motivation than other years (Table 1). Although they have high motivation, the chance of participation especially to do clinical practice were very limited. Whereas in clinical phase, especially in students year 6 , the motivation was the lowest compared to other years, but the mean of participation was the highest (Table 1). This is might be caused not only by the broader opportunities to do clinical practice, but also the clinical phase curriculum which forces the students to participate in clinical practice even though the motivation was low. Table 1 shows that the mean of personal reflection on the pre-clinical stage tend to be similar. Increasing the chance to clinical practice were related with increasing the student's participation. More experience may augment the student's reflection.

In the proposed model, the hypothesis stated that only participation which positively and directly associated to professional identity. Our study found that not only participation but also motivation has positive and direct association with professional identity. Previous study has shown that motivation and identity are two constructs that are closely related..$^{25}$ The engagement of student in the educational process is closely linked with the idea of self about who s/he is, what will be and what s/he will be like. There is a reciprocal and integrated relationship between academic motivation and identity that will appear in the dynamics of everyday life of medical student.

Besides making modifications to the model hypothesized, we also analyzed based on the stages of education, that are pre-clinic and clinic. This is because these two stages have a different learning 
environment and a curriculum. Results showed that pre-clinical model resembles the modification model of professional identity, while the clinical model was different.

Our model showed that self-efficacy is an important construct that plays a role in student participation. This was especially evident in clinical model, in which self-efficacy was the strongest predictor for participation. This finding is consistent with a study by Robbins et al which showed that academic self-efficacy is the strongest predictor of academic achievement and performance, while the second strongest predictor of achievement was motivation. Bandura asserted that formal education should have the main objective of providing intellectual tools, selfefficacy and intrinsic interest to students to prepare longlife learning. ${ }^{11}$

We found that the relationship between constructs in the professional identity model differed from that in the clinical professional identity model. In the clinical model, personal reflection significantly associated with participation. This may be due to the clinical experience of the clinical students that required more reflection ability compared to the preclinical students. Reflection is a process by which students find the meaning of his/her experience. Reflection can be a mediator between experience and identity, ${ }^{13}$ therefore the ability for reflection is needed.

In the clinical model, the curriculum in action perceived by students did not have an effect towards participation. This implies that with the same perception of the curriculum, students with higher self-efficacy showed higher participation compared to those with low self-efficacy. Learning in clinical education system is not very much bound in the formal processes. Students are required to be able to direct themselves in learning (self-directed learning). There are two boundaries in clinical education, for instance educational and patient care processes. There are educational process that takes place in synergy with patient care (for example: bed side teaching, mini-CEX), but there are educational process that takes place without patient's care process (for example tutorials, reading journals, literature review) and patient care process that is not associated with educational process. $^{26}$ Students learn not only from formal education process, but also from patient care process. The enthusiasm of students to participate in patient care is very important, not only in the context of fulfilling tasks in the educational curriculum but also in context of contributing to patient care. Medical teachers, especially clinical educators, need to understand and implement the learning that encourages self-efficacy. ${ }^{27}$

The clinical professional identity model explained $62 \%$ of variance of participation. The model showed that internal conditions of self (e.g. selfefficacy and personal reflection) had a greater effect on participation than external, for instance, social interaction or curriculum in action. This condition was different with the pre-clinical model. Social interaction had the greatest association with participation among pre-clinical students. This indicates that social support, especially from friends, had essential role for students during the pre-clinical study. Psychological stress and low social support could increase the likelihood of having poor academic self-perception among medical students. ${ }^{28}$ The results also support the statement about the importance of student organizations which provide more chance for students to have social interaction and to participate in several medical activities which may have a role in professional identity development. ${ }^{21,29}$

In clinical model, the results showed that the association between participation and professional identity was less significant. This may be caused by the assessment of participation which was based on the activities only in last year, whereas the assessment of professional identity was not based on certain period. Students of year 5 and 6 have similar intensity of activities or participation in last year, but the professional identity of students of year 6 may be more developed because of the accumulation of their experience and educational process. From previous qualitative study, participation could foster medical student's motivation. ${ }^{21,30}$

Although the analysis of PLS-SEM can provide path coefficient which indicating the effect of predictor variables on criterion variables, this study has not been able to prove cause-effect relationship. This why we used the word "associate" instead of "influence" 
or "affect". To be able to show the cause-effect relationship, there are requirements that must be met, for instance temporality (cause precedes effect), a strong correlation and not a spurious correlation. This study, which used cross-sectional design in collecting data, can not meet the temporality requirement. The model had explained only $40 \%$ of the professional identity variance. It implied that there are still many issues or constructs that have not been explored. The student's perception that he/she have contributed, being valued, appreciated, and trusted by patients or community should be more represented in the model. These perceptions are the impacts of participation and it may mediate the association between participation and identity. Participation without appreciation and constructive feedback may cause declining identity. Future research should explore another construct or change the role of constructs that have been studied in this model. Research with experimental design could be done to provide stronger evidence of cause-effect relationship in the model of professional identity.

One of the limitations of this study was all variables assessed based on the perception of the students. This can lead to same subject bias in which the predictor and the criterion variable were asessed by the same subject. Consideration of this same source subject was because only the individual students themselves who know the correct internal conditions of themselves and the things that happened to him. Motivation, self-efficacy, personal reflection and professional identity are individual internal condition which only can be judged by him/herself. Participation in this study assessing the activity inside and outside the curriculum, which can not be recorded by the faculty even in the educational process.

\section{CONCLUSION}

This research concluded that professional identity of medical students could be explained by motivation and participation. Motivation had greater association on professional identity than do participation. Selfefficacy had greater association on participation than do social interaction and curriculum in action perceived by students. Based on the model, within the medical education processes, academic motivation of students should be maintained and fostered and participation should be supported.

\section{ACKNOWLEDGEMENT}

We thank Astri Ferdiana for assistance in proofing english and comments on an earlier manuscript, although any errors are our own and should not tarnish the reputations of her.

\section{DECLARATION OF INTEREST}

Beyond the authors' personal involvements in medical education, they have no conflicts of interest to declare. The authors alone are responsible for the content and writing of the paper.

\section{REFERENCES}

1. Wenger E. Communities of Practice: Learning, Meaning, and Identity. Cambridge University Press;1998.

2. Adams K, Hean S, Sturgis P, Clark JM. Investigating the factors influencing professional identity of firstyear health and social care students. Learn. Heal. Soc. Care. 2006;5:55-68.

3. Bleakley A, Bligh J, Browne J. Medical education for the future, identity, power and location. Springer; 2011.

4. Nystrom S. The Dynamics of Professional Identity Formation: Graduates' Transitions from Higher Education to Working Life. Vocat. Learn. 2009;2:118.

5. Wenger E. in Communities of practice and Social Learning Systems (ed. Blackmore, C.) Springer Verlag and the Open University; 2009.

6. Dornan $\mathrm{T}$, Boshuiszen H, King N, Scherpbier A. Experience-based learning: a model linking the processes and outcomes of medical students' workplace learning. Med. Educ. 2007;41:84-91.

7. Seddon K, Skinner NC, Postlethwaite KC. Creating a model to examine motivation for sustained engagement in online communities. Educ. Inf. Technol. 2007;13:17-34.

8. Katoma V, Hendrix D. Modeling Contextual Factors Affecting Online Participation in Communities of Practice (Cops) in Corporate Entities. Int. J. Bus. Soc. Sci. 2014;5:151-61.

9. Billet S. Relational Interdependence Between Social and Individual Agency in Work and Working Life. Mind, Cult. Act. 2006;13(1):53-69 
10. Deci E, Ryan RM. Intrinsic motivation and selfdetermination in human behavior. Springer; 1985.

11. Bandura A. Self-efficacy: the exercise of control. W.H. Freeman; 1997.

12. Robbins SB, et al. Do psychosocial and study skill factors predict college outcomes? A meta-analysis. Psychol. Bull. 2004;130:261-88.

13. De Weerdt S, Bouwen R, Corthouts F, Martens H. Identity transformations as intercontextual process. Ind. High. Educ. 2006;2:317-25.

14. Baingana $\mathrm{R}$, et al. Learning health professionalism at Makerere University: an exploratory study amongst undergraduate students. BMC Med. Educ. 2010;10:76.

15. Ngasa SN, et al. Prevalence and factors associated with depression among medical students in Cameroon: a cross-sectional study. BMC Psychiatry 2017;17:216.

16. Susani YP, Rahayu GR, Sanusi R, Prabandari YS, Mardiwiyoto H. Model Identitas Profesional Mahasiswa Kedokteran. Universitas Gadjah Mada; 2015.

17. Vallerand RJ, Pelletier LG, Blais MR, Briere NM, Senecal C, Vallieres EF. The academic motivation scale: a measure of intrinsic, extrinsic, and amotivation in education. Educ. Psychol. Meas. 1992; 52:1003-17.

18. Solberg VS, Obrien K, Villareal P, Kennel R, Davis B. Self-efficacy and Hispanic college students: Validation of the College Self-Efficacy Instrument. Hisp. J. Behav. Sci. 1993;15:80-95.

19. Aukes L. Personal Reflection in Medical Education [dissertation]. University Medical Center Groningen; 2008.

20. Wong KK. Partial Least Squares Structural Equation Modeling (PLS-SEM) Techniques Using SmartPLS. Mark. Bull. 2013;24:1-32.

21. Susani YP, Rahayu GR, Sanusi R, Prabandari YS, Harsono. Medical Student's Participation for
Developing Professional Identity. MedEdPublish 2015;5:1-12.

22. Mak DB, Miflin B. Clinical audit in the final year of undergraduate medical education: Towards better care of future generations. Med. Teach. 2012;34:e251-7.

23. Lyon P, Letschka P, Ainsworth T, Haq I. An exploratory study of the potential learning benefits for medical students in collaborative drawing: creativity, reflection and 'critical looking'. BMC Med. Educ. 2013;13:86.

24. Green MJ. Comics and Medicine: Peering Into the Process of Professional Identity Formation. Acad. Med. 2015;90:1.

25. Kaplan A, Flum H. Motivation and Identity: The Relations of Action and Development in Educational Contexts-An Introduction to the Special Issue. Educ. Psychol. 2009;44:73-7.

26. Steven K, Wenger E, Boshuizen H, Scherpbier A, Dornan T. How clerkship students learn from real patients in practice settings. Acad. Med. 2014;89:469_ 76.

27. Artino AR. Academic self-efficacy: from educational theory to instructional practice. Perspect. Med. Educ. 2012;1:76-85.

28. Yamada Y, Klugar M, Ivanova K, Oborna I. Psychological distress and academic self-perception among international medical students : the role of peer social support. BMC Med. Educ. 2014;14:1-8.

29. Vivekananda-Schmidt P, Crossley J, Murdoch-Eaton D. A model of professional self-identity formation in student doctors and dentists: a mixed method study. BMC Med. Educ. 2015;15:1-9.

30. Dornan T, Scherpbier A, Boshuizen H. Supporting medical students' workplace learning: experiencebased learning (ExBL). Clin. Teach. 2009;6:167-71. 